\title{
THE INFLUENCE OF STUDENTS' KNOWLEDGE AND ATTITUDE TOWARD FUNCTIONAL FOODS CONSUMPTION BEHAVIOR
}

\author{
Siti Afina*)1, Retnaningsih*) \\ *Department of Family and Consumer Sciences, Faculty of Human Ecology, \\ Bogor Agricultural University \\ ${ }^{1}$ Corresponding author: afinasiti21@gmail.com
}

\begin{abstract}
The objectives of this research was to analyze the influence of student's knowledge and attitude toward functional foods consumption behaviour. This research used cross-sectional study design and took place at Bogor Agricultural University. Samples of this research were 204 undergraduate students that chosen using simple random sampling method. The data were collected by a selfadministered technique using questionnaires. The results showed that the average of functional foods consumption frequency was 47 times a month and the number of types consumed was 7 kinds. The results of Pearson correlation test showed that student's allowance, attitudes, and frequency of functional foods consumption were correlated significant and positive. Factors that have a significant positive influence toward consumption frequency were the allowance and student's attitude. The number of functional foods types consumed was influenced by student's attitude.
\end{abstract}

Keywords: attitude, consumption behaviour, functional foods, knowledge, young consumer

\begin{abstract}
Abstrak. Penelitian ini bertujuan menganalisis pengaruh pengetahuan dan sikap mahasiswa terhadap perilaku konsumsi pangan fungsional. Penelitian ini menggunakan desain cross sectional study dengan lokasi penelitian di Institut Pertanian Bogor. Contoh dalam penelitian ini adalah 204 mahasiswa Institut Pertanian Bogor yang dipilih secara acak sederhana. Pengambilan data dilakukan dengan teknik self-administered menggunakan alat bantu kuesioner. Hasil penelitian menunjukkan bahwa mahasiswa mengonsumsi pangan fungsional ratarata $47 \mathrm{kl} / \mathrm{bl}$ dan 7 jenis. Hasil uji korelasi Pearson menunjukkan uang saku dan sikap mahasiswa berhubungan positif signifikan dengan frekuensi konsumsi pangan fungsional. Faktor yang berpengaruh positif signifikan terhadap frekuensi konsumsi pangan fungsional adalah uang saku dan sikap. Jumlah jenis pangan fungsional yang dikonsumsi hanya dipengaruhi oleh sikap.
\end{abstract}

Kata kunci: konsumen muda, pangan fungsional, pengetahuan, perilaku konsumsi, sikap 


\section{Introduction}

The concept of functional foods was first introduced in Japan in 1984 which refers to processed food with ingredients that can help improving the functions in the human body other than its main nutrition (Muchtadi, 2012). The regulation on functional foods in Indonesia has been regulated in the Regulation of the Head of the Food and Drug Administration (PKBPOM) in 2011 which contains the claims that are allowed to be included on the label or advertisement of processed food products that can also help identifying functional foods. There are no data on the number of functional foods production and trade in Indonesia, but functional foods and beverages have been circulating in the Indonesian market which contain fibre, probiotic bacteria, honey, taurine, and so on which are expected to give physiological effects on the body (Winarti, 2010).

Research on functional foods have been widely conducted, and the results were shown with different attitudes in each region, depending on the geographical area in which the research was conducted (Urala et al., 2011; Carrillo et al., 2013). The behaviour of functional foods consumption was influenced by demographic factors that contribute to attitudes and behaviours of acceptance of functional foods (Gilbert, 2000; Bech-Larsen \& Grunert, 2003; Urala \& Lähteenmäki, 2003; Verbeke, 2005). Sääksjärvi et al. (2009) stated that consumers with high-income level affected the high consumption of functional foods. In addition to income, some general results emerging from recent research reveal that female consumers had higher knowledge and had more positive attitudes toward functional food than male consumers (Ong et al. 2014; Brečić et al., 2014).

In addition to demographic factors such as age, gender, allowance, and individual factors such as knowledge (Sääksjärvi et al., 2009) and attitudes also affect the behaviour of functional foods consumption (Urala \& Lähteenmäki, 2007; Chen, 2011). Previous studies have revealed that consumers knowledge of functional foods varies widely (Menrad, 2003; De Jong et al., 2004). Bogue et al. (2005) shown that consumer's knowledge has a positive influence on consumption behaviour of functional foods. Positive consumer's attitudes towards functional food are important factors in the high level of functional food consumption (Seechurn et al., 2009; Dogan et al., 2011; Rezai et al., 2012; Marina et al., 2014;).

Based on research conducted by Carrillo et al. (2013), students are included in the category of young consumers (aged 18-34 years), and the results of the research showed that young consumers consumed functional food more than middle-aged consumers. Rezai et al., (2012) suggested that young consumers were more open to new things and showed more positive attitude than the middle-aged consumers. Looking at such a situation, related to the age and attitude of consumers to functional foods, producers are more focused on young consumers as potential consumers for functional foods products. 
Students as young consumers can easily absorb information well when presented information about new products. The introduction of functional foods products in Indonesia are still new if compared to developed countries. Nevertheless, some people have consumed functional foods products without knowing that the foods they consumed are functional foods. Students, for example, the density of their activities make them not much pay attention to the type of food and drinks they consume. Research on the nutritional knowledge of the students is already widely done, but more specialized research on functional foods knowledge has not been done considering the information about functional foods is still small in Indonesia, so that makes this research important to do. Based on the description, this study aimed to (1) analyze the knowledge, attitude, and behavior of functional food consumption in the students, (2) to analyze the correlation of knowledge, attitude, and behavior of functional food consumption to the students; and (3) analyze the influence of student's knowledge and attitude toward functional food consumption behavior.

\section{Method}

This research used cross-sectional study design with data retrieval time conducted from May to June 2017. The location was selected purposively at Bogor Agricultural University (IPB) with consideration that IPB is an agriculture campus which does many research in food field including one of them is functional foods. Students of IPB are considered to have adequate knowledge because more exposure to functional food products is widely studied in IPB than ordinary people in general. The population in this study were undergraduate students in $2^{\text {nd }}, 4^{\text {th }}$ and $6^{\text {th }}$ semester, with the 10.599 students of total population. The sample were selected randomly used the Slovin formula with leniency of 0.07 . The calculation result with the Slovin formula indicated that 200 persons should be taken as a minimum number of samples. A total of 300 students were selected, but only 204 students are willing to be respondents. Primary data collection was conducted by $a$ self administered technique using questionnaire. Functional foods knowledge questionnaire was translated from Sääksjärvi et al. (2009) with Cronbach's alpha of 0.787. Consumers' attitudes was measured using the questionnaires translated from the consumers' attitude questionnaire to functional food by Urala and Lähteenmäki (2007) with Cronbach's alpha as 0.787. The functional foods consumption behaviour was divided into two, consumption and the number of types consumed. The consumption behaviour questionnaire listed the types of functional foods, brands, volumes, and frequency of consumption per day, per week, and per month.

Data analysis using Microsoft Excel 2010 and Statistical Package for Social Science (SPSS) version 16. Data processing includes coding, scoring, entrying, cleaning, and analyzing. Data analysis was done statistically through descriptive test and inferentia test. Descriptive test included average, standard 
deviation, minimum value, and max value. Inferentia test includes ChiSquare test, Pearson correlation test and multiple linear regression tests. The variables studied in this study were scored according to the scale used. The frequency and number of species consumed are measured using the actual score earned. The actual frequency of consumption score was obtained from the questionnaire filling out questions about consumption per day, per week and month. The frequency of consumption then equated the unit into consumption per month. The number of types obtained from the total type of functional food consumed by the students based on ten types of functional foods mentioned in the questionnaire. The variables scores that were transformed into index are objective knowledge variables, subjective knowledge, and attitudes differentiated into categories: low (0-59), moderate (60-80), and high (81-100) (Khomsan et al. 2009).

\section{Result}

\section{Overview of Functional Food Products}

According to PKBPOM RI (2011) about the monitoring of claims in labels and advertisements of processed foods defines functional foods as processed food containing one or more food components based on scientific studies have certain physiological functions in beyond its basic function, proved not harmful and beneficial to health. The functional foods have to meet the following requirements: 1) contains the type of food component in the amount corresponding to the limits set by PKBPOM RI in 2011;2) has sensory characteristics such as appearance, color, texture or consistency and racial ideals that consumers can accept; 3) and served and consumed as food or drinks. Functional foods claimed in two ways: the claim contains other functions to its components, namely dietary fibre, phytosterols, and a fitostanol drisk claims reduce disease with its components namely; folic acid, calcium, alcohol sugar, dietary fibre, phytosterols and phytostanol, peptides, and soy isoflavones.

Functional food in this study focused on ten food groups that claimed to contain functional components that are different from conventional foods. Functional foods have been through research and proven to contain functional components that can provide benefits to the body. Consumption of probiotic yoghurt may decrease the symptoms of lactose malabsorption and increase the natural resistance of the gastrointestinal tract (Winarti, 2010). Oatmeal with $\beta$-glucan is believed to lower cholesterol levels in the blood and reduce the risk of coronary heart disease. Soy contains protein and fat and is believed to prevent the onset of various diseases such as cardiovascular, cancer, osteoporosis, and relieve symptoms of menopause (Hasler, 1998) in Muchtadi (2012). Referring to Urala and Lähteenmäki (2007), functional food group that studied the frequency of consumption that is : (1) fruit and vegetable juices with 
added vitamins, (2) bread and whole-grain crackers with fiber, (3) oatmeal with $\beta$-glucan, (4) the snack bar with fiber, (5) yogurt with probiotics, (6) lowfat milk, (7) processed fish with omega-3, (8) processed products, processed tea products, and (10) isotonic drinks.

\section{Characteristics of the Students}

The age of the students ranged from 17 to 21 years old with the average age of 19.4 years and included into the late adolescent category according to the Ministry of Health of the Republic of Indonesia in 2009. In this study, the most students are female where the proportion of students are 51.5 percent of female and 49.5 of men. The distribution of student pocket money per month ranges from $\mathrm{Rp} 300.000$ to $\mathrm{Rp} 3.500 .000$ with an average of $\mathrm{Rp} 976.000$. The results showed that more than half of the students $(56.4 \%)$ had an allowance ranging from $\mathrm{Rp}$ 600.001 to $\operatorname{Rp} 200.000$.

\section{Objective Knowledge of Functional Foods}

The results showed that students had low objective knowledge of functional foods. A total of more than $50 \%$ of students only managed to answer correctly as many as six items of questions from 15 questions available. This showed that student's knowledge of functional foods was still lowlow. The lowest knowledge of students of functional foods was about the benefits after consuming functional foods $(14 \%)$. The most widely known information by students is related to the knowledge that functional food can be consumed by anyone, not just for those who have health problems. As many as $82.4 \%$ of students successfully answered correctly on that question. Based on the distribution of answers, more than half of students already know that functional foods prices are more expensive than conventional food, functional foods are expensive because of the research costs, functional foods are not only juices and dairy products, and functional foods are not only in Indonesia.

\section{Subjective Knowledge of Functional Foods}

Subjective knowledge consists of three questions that focused on a large area of knowledge. The results showed that more than half of the students $(58.8 \%)$ did not know or were wrong to answer a name of functional foods brands. Students who successfully name the brands of functional foods, the most commonly mentioned were brands of yoghurt and oatmeal products. In addition, the question of how long has known functional foods, most students (87. 3\%) just know the term of functional foods when the survey was done, and only one student $(0.5 \%)$ who know the functional foods terms more than one year. Student's perceptions of how they know about functional foods more than half $(57.8 \%)$ stated very ignorant about functional foods.

The results showed that the student's objective knowledge of more than half of the students $(57.8 \%)$ was at a low level of knowledge with scores ranging from 0 to 93 (correctly answered 14 questions out of 15) (Table 1). The average 
score of objective knowledge achieved is 46.5 and considered low. It is indicating that the average student could not correctly answer more than seven questions out of 15 questions. The level of subjective knowledge of students was also low, the average score was 32.2 with the range between 0 to 83.3 , and the largest proportion is in a low category $(92.2 \%)$. This means that most student perceives themselves have less knowledge of functional foods although objective knowledge achieved a higher score than subjective knowledge. Based on the results, it is known that the level of knowledge of the students of functional foods both objective and subjective was still low.

Tabel 1 Distribution of students based on objective and subjective knowledge

\begin{tabular}{lrrrr}
\hline \multirow{2}{*}{ Knowledge Level } & \multicolumn{2}{c}{ Objective } & \multicolumn{2}{c}{$\begin{array}{c}\text { Subjective } \\
\text { Knowledge }\end{array}$} \\
\cline { 2 - 5 } & \multicolumn{1}{c}{ Knowledge } & \multicolumn{1}{c}{ Know } \\
\hline Low $(<60)$ & 118 & 57.8 & 188 & 92.2 \\
Moderate $(60-80)$ & 79 & 38.7 & 10 & 4.9 \\
High $(>80)$ & 7 & 3.4 & 6 & 2.9 \\
Total & 204 & 100.0 & 204 & 100.0 \\
\hline
\end{tabular}

\section{Attitude}

The results indicated that the attitude of students based on the distribution of answers on the dimensions of attitude showed that the dimension of necessity obtained the highest rate of 82.3 . This result is in line with the study of Carrillo et al., (2013) who found that necessity as the most supportive dimension of attitude to shape attitudes toward functional food and followed by safety as the second most favourable dimension. Based on the results, student's attitudes based on the overall dimensions of attitude showed a fairly agree tend to agree on functional foods. Based on student's total attitude toward functional foods, the achievement index score ranged from 40 to 89 with an average of 68 . 3. The largest proportion of total student attitudes was in the moderate $(83.8 \%)$ category (Table 2$)$.

Tabel 2 Distribution of students based on attitude towards functional foods

\begin{tabular}{|c|c|c|c|c|c|c|c|c|}
\hline \multirow{3}{*}{$\begin{array}{l}\text { Attitude } \\
\text { Dimensions }\end{array}$} & \multicolumn{6}{|c|}{ Category } & \multirow{2}{*}{\multicolumn{2}{|c|}{ Total }} \\
\hline & \multicolumn{2}{|c|}{ Low } & \multicolumn{2}{|c|}{ Moderate } & \multicolumn{2}{|c|}{ High } & & \\
\hline & $\mathrm{n}$ & $\%$ & $\mathrm{n}$ & $\%$ & $\mathrm{n}$ & $\%$ & $\mathrm{n}$ & $\%$ \\
\hline Reward & 66 & 32.4 & 120 & 58.8 & 18 & 8.8 & 204 & 100.0 \\
\hline Min-Max & & & 28.1 & & & & & \\
\hline Average \pm SD & & & 64.5 & & & & & \\
\hline Necessity & 5 & 2.5 & 66 & 32.4 & 133 & 65.2 & 204 & 100.0 \\
\hline Min-Max & & & 28.1 & & & & & \\
\hline Average \pm SD & & & 82.3 & & & & & \\
\hline Confidence & 45 & 22.1 & 63 & 30.9 & 96 & 47.1 & 204 & 100.0 \\
\hline Min-Max & & & 26.7 & & & & & \\
\hline Average \pm SD & & & 67.4 & & & & & \\
\hline Safety & 13 & 6.4 & 165 & 80.9 & 26 & 12.7 & 204 & 100.0 \\
\hline Min-Max & & & 25 & & & & & \\
\hline Average \pm SD & & & 71.2 & & & & & \\
\hline
\end{tabular}




\begin{tabular}{|c|c|c|c|c|c|c|c|c|}
\hline \multirow{3}{*}{$\begin{array}{l}\text { Attitude } \\
\text { Dimensions }\end{array}$} & \multicolumn{6}{|c|}{ Category } & \multirow{2}{*}{\multicolumn{2}{|c|}{ Total }} \\
\hline & \multicolumn{2}{|c|}{ Low } & \multicolumn{2}{|c|}{ Moderate } & \multicolumn{2}{|c|}{ High } & & \\
\hline & $\mathrm{n}$ & $\%$ & $\mathrm{n}$ & $\%$ & $\mathrm{n}$ & $\%$ & $\mathrm{n}$ & $\%$ \\
\hline Total Attitude & 20 & 9.8 & 171 & 83.8 & 13 & 6.4 & 204 & 100.0 \\
\hline Min-Max & & & & & & & & \\
\hline Average \pm SD & & & 68.3 & & & & & \\
\hline
\end{tabular}

\section{Functional Foods Consumption Behavior}

The results showed the frequency of functional foods consumption in students ranged from 8 to 96 times a month with average dietary consumption of 47 times per month. The largest proportion of students' consumption frequency was in moderate categories $(46.1 \%)$ (Table 3$)$. The results showed that the functional foods type consumed ranged from 2 to 9 types (Table 3) with the average type of functional foods consumed by the students of 7 types. Most students eat functional foods more than seven types (86.3\%).

The results showed that bread and wheat biscuits with fiber were the most consumed products $(92.6 \%)$, followed by fruit or vegetable juice with vitamin supplements $(91.2 \%)$, soy products $(85.3 \%)$, isotonic drinks $(82.5 \%)$, yoghurt $(69.6 \%)$, low-fat milk $(69.1 \%)$, oatmeal with $\beta$-glucan $(66.7 \%)$, snack bars with fiber $(60.3 \%)$, tea-processed products $(58.3 \%)$, and the fewest consumed by students is a processed fish product with omega-3, which is only $53.9 \%$ of students who consumed it in last month. Wheat processed products consumed by many students because it tastes good, makes full, and affordable prices. The widely consumed soybean products are tempeh which is a traditional Indonesian food heritage and has been scientifically proven to contain soy isoflavones that can reduce the risk of coronary heart disease.

Tabel 3 Distribution of students by frequency and number of types functional foods consumed

\begin{tabular}{lrr}
\hline Consumption Behavior & $\mathrm{n}$ & $\%$ \\
\hline Consumption Frequency & & \\
Low (<31 times/month) & 54 & 26.5 \\
Moderate (31-60 times/month) & 94 & 46.1 \\
High (>60 times/month) & 56 & 27.5 \\
Total & 204 & 100.0 \\
\hline Number of types consumed & & \\
Less (0-3 types) & 4 & 2.0 \\
Moderate (4-6 types) & 20 & 11.7 \\
High (7-10 types) & 180 & 86.3 \\
Total & 204 & 100.0 \\
\hline
\end{tabular}

\section{Correlation between Characteristics of the Students, Knowledge, Attitudes, and Functional Foods Consumption Behavior}

Chi-Square test results showed that there was no relationship between gender and the frequency of consumption and the number of types consumed. Pearson correlation test results showed that allowance is positively correlated with the frequency of functional food consumption and there is a positive relationship between attitude with consumption frequency and the 
number of functional food type consumed (Table 4). This is in line with Sääksjärvi et al., (2009) which stated that income and consumer attitudes toward functional food associated with behavioural consumption of functional foods. Although the test results pointed that knowledge did not significantly associate with the consumption behaviour, but knowledge with a significant positive attitude with correlation coefficient as 0. 352. Sääksjärvi et al., (2009) suggested that attitudes can mediate consumer knowledge with functional foods consumption behaviour. The results showed that students with positive attitude, will consumed functional foods with high frequency and many numbers of type as well.

Table 4 Correlation of Student Characteristics, Knowledge, and Attitudes with Functional Foods Consumption Behavior

\begin{tabular}{|c|c|c|c|c|c|}
\hline \multirow[b]{2}{*}{ Variables } & \multicolumn{5}{|c|}{ Correlation coefficient } \\
\hline & $\begin{array}{l}\text { Objective } \\
\text { Knowledge }\end{array}$ & $\begin{array}{l}\text { Subjective } \\
\text { Knowledge }\end{array}$ & Attitudes & $\begin{array}{l}\text { Consumption } \\
\text { Frequency }\end{array}$ & $\begin{array}{l}\text { Number of } \\
\text { Types } \\
\text { consumed }\end{array}$ \\
\hline Gender $^{1}$ & -0.016 & 0.090 & -0.074 & 0.074 & -0.055 \\
\hline Allowance $^{2}$ & 0.106 & 0.096 & 0.053 & $0.172 *$ & -0.027 \\
\hline Objective & & & $0.352 * *$ & 0.087 & 0.043 \\
\hline Knowledge $^{2}$ & & & & & \\
\hline Subjective & & & $0.205 * *$ & 0.092 & 0.067 \\
\hline Knowledge $^{2}$ & & & & & \\
\hline Attitude $^{2}$ & & & & $0.245 * *$ & $0.262 * *$ \\
\hline Rewards & & & & $0.205^{*}$ & $0.201 * *$ \\
\hline Necessity & & & & $0.146^{*}$ & $0.149 *$ \\
\hline Confidence & & & & $0.144 *$ & $0.173^{*}$ \\
\hline Safety & & & & $0.179 *$ & $0.212 * *$ \\
\hline
\end{tabular}

\section{The Influence Factors toward Functional Foods Consumption Behavior}

The results of multiple linear regression tests showed that characteristics of students (age and allowance), knowledge, and attitude significantly influenced consumption behaviour and can be seen from F-count of 3.334 (Table 5). Adjusted R square was 0.065 means that 6.5 percent all independent variables that studied influence toward consumption frequency behaviour, and the remain $(83.5 \%)$ was influenced by the variables that was not included in this research (Table 5). The multiple regression tests in the second model which was the number of food types that consumed also showed the same result, but with the value of adjusted $\mathrm{R}$ square was smaller, that is 048 , which means the influence of variables studied only 4.8 percent. The allowance had a significant affect on the frequency of functional foods consumption $(\beta=0$. 095). This means that every increase of ten thousand rupiah of allowance will increase the frequency of functional food consumption by 0.095 times. Attitudes significantly influence the frequency of functional food consumption $(\beta=0.752)$. This means that every one point index of attitude increasing will promote the functional foods 
functional fraction of 0.752 times. In addition, attitudes also positively influence the number of types of functional food consumed $(\beta=0.042)$. This means that every one point index of attitude increasing will increase the number of types of food consumed by 0.042 times.

Table 5 The result of regression analysis of factors influencing the functional food consumption behaviour

\begin{tabular}{|c|c|c|c|c|c|c|}
\hline \multirow[b]{2}{*}{ Variables } & \multicolumn{3}{|c|}{ Consumption Frequency } & \multicolumn{3}{|c|}{ Number of types consumed } \\
\hline & $\begin{array}{l}\text { Unstandardi } \\
\text { zed } \\
\text { coefficient } \\
\text { B } \\
\end{array}$ & $\begin{array}{c}\text { Standardize } \\
\mathrm{d} \\
\text { Coefficient } \\
\beta \\
\end{array}$ & Sig. & $\begin{array}{c}\text { Unstandardiz } \\
\text { ed } \\
\text { coefficient } \\
\text { B } \\
\end{array}$ & $\begin{array}{c}\text { Standardiz } \\
\text { ed } \\
\text { Coefficient } \\
\beta \\
\end{array}$ & Sig. \\
\hline Constant & 23.380 & & 0.000 & 4.845 & & 0.001 \\
\hline $\begin{array}{l}\text { Objective } \\
\text { Knowledge (0-100) }\end{array}$ & -0.048 & -0.042 & 0.664 & -0.006 & 0.102 & 0.297 \\
\hline $\begin{array}{l}\text { Subjective } \\
\text { knowledge }(0-100)\end{array}$ & 0.030 & 0.033 & 0.724 & 0.003 & 0.075 & 0.430 \\
\hline Attitude $(0-100)$ & 0.752 & 0.250 & $0.001 * *$ & 0.042 & 0.278 & $0.000 * *$ \\
\hline $\begin{array}{l}\text { Gender }(0=\text { female; } \\
1=\text { male })\end{array}$ & 4.493 & 0.099 & 0.155 & -0.088 & -0.038 & 0.586 \\
\hline $\begin{array}{l}\text { Allowance (Rp } \\
\text { 0000) }\end{array}$ & 0.095 & 0.135 & $0.050^{*}$ & 0.001 & -0.037 & 0.591 \\
\hline $\mathrm{F}$ & 3.334 & & & & & 2.724 \\
\hline Adjusted $\mathrm{R}^{2}$ & 0.065 & & & & & 0.048 \\
\hline Sig & $0.002 * *$ & & & & & $0.015^{* *}$ \\
\hline
\end{tabular}

\section{Discussion}

The results of regression test showed that knowledge did not influence consumers behaviour, both frequency and type of functional foods, eventhough theoretically, individual factors such as consumer knowledge can influence consumption behaviour but in this case, it didn't apply. According to Wansink et al., (2005) to consume functional foods, people need to know "what" and "why". Without special knowledge, consumers tend to buy functional food with occasional frequencies and random fluctuations instead of being consistent with functional foods. In line with Marina et al., (2014), consumers with low knowledge of functional foods, buy functional food irregularly. This is why knowledge has no significant effect on consumption behaviour of functional food.

The result of the research showed that the student's knowledge of functional foods was low, but the students' consumption frequency was at the moderate level. This result was in line with Morawska et al., (2016) that suggested students who didn't have good knowledge about functional foods turned out to consume functional foods quite often. According to Sääksjärvi et al. (2009), knowledge through attitude will influence consumption behaviour so it can be said that knowledge is not directly influence the consumption behaviour. Based on the theory of the formation of consumer's attitude, one of the components of attitude formers is cognitive which is consumer's belief to a 
product contains a certain component or often referred to consumer's knowledge (Sumarwan, 2011). The result of Pearson correlation test was significantly positive between knowledge and attitude, which means the higher the knowledge the higher the attitude will be.

In addition, the low level of students' knowledge of functional foods may be due to several factors. Various reasons can support the individual in determining interest and tendency to consume a product, such as a price and taste of functional foods (Marina et al., 2014; Morawska et al., 2016). According to Morawska et al., (2016), students do not realize that they have consumed functional foods because they consume functional foods based on preference to a certain food. Students consume functional food products because of their fondness for the product not because they want to get the benefits contained by the functional foods. This research is not in line with Krutulyte et al., (2009) that indicating consumers will feel the desire to consume a product if they are known the functional components in the products.

The results showed that the attitude significantly positive influence on the frequency of consumption and the number of types of functional food consumed. This is in line with Beardswroth et al., (2002) and Siró et al., (2008) that positive consumer attitudes influence the level of functional food consumption. Based on the dimensions of attitude such as rewards, necessity, confidence, and safety, Urala and Lahteenmaki (2003) suggested that the need to have a healthy lifestyle is a factor that can lead to consumer decisions in consuming functional foods. The highest dimension of attitude that influence the functional foods consumption behaviour is a necessity. This is in line with Carrillo et al., (2013), but unlike Chen's (2011) study, which found that the reward and confidence dimensions are the dominant dimensions that are most likely to affect functional food consumption behaviour.

The results of correlation test between students' characteristics (gender and allowance) with the frequency and quantity of type consumed have shown that the allowance is positively correlated with the frequency of functional foods consumption. This is in line with Sääksjärvi et al., (2009) and Florea et al., (2016) that consumers with high-income consumed functional foods more than consumers with low-income. This can be due to consumers who have greater allowance will be able to buy functional foods whose price is more expensive than conventional food. Gender did not correlate with the frequency nor the number of types consumed. This is in line with Verbeke (2005) who found that there is no correlation between gender and functional foods consumption behaviour but contradicts with Ong et al., (2004) which found that female consumers consume functional foods more than men. According to Urala and Lähteenmäki (2007) and Siró et al., (2008), this is because women pay more attention to food and health issues than men. The absence of a relationship between gender and consumption behaviour in this research can be caused by the lack of awareness of IPB students about maintaining health and their low knowledge of functional foods. 
The results of regression test showed that attitude and allowance affect significantly positive toward frequency of functional foods consumption. This is in line with the research of Ares and Gambaro (2007), Verbeke (2005), and Florea et al., (2016) that high attitudes and allowances can influence consumers to consume high functional foods as well. The number of types consumed of functional foods was influenced only by attitudes. According to Morawska et al., (2016), students consume functional foods by type due to the level of their preference and the influence of the mass media. The results of regression test showed that the characteristics of the students (gender and allowance), knowledge, and attitude together have a significant affect on consumption behaviour (frequency and number of types). The adjusted $\mathrm{R}$ square was 0.065 indicated that only 6.5 percent of frequency of functional food consumption described by the independent variables, the remain was explained by other variables that was not examined. Other possible variables that was not studied are the reference group, motivation, perceptions of functional food, health status, and health awareness.

This study has several limitations. The types of functional foods classified in this study only ten types and the absence of a special logo for functional food products causes many students who have difficulty distinguishing functional food with ordinary food. In addition, data collection used a self-administered technique to enable students to provide answers according to their perceptions. Nor does this study address the expenditure of students allocated for functional food consumption.

\section{Conclusion and Recommendation}

\section{Conclusion}

Attitude dimension with highest achievement score was a necessity, followed by safety, confidence, and reward. The most commonly consumed type of functional food was processed wheat with fibre, followed by fruit and vegetable juices with added vitamins, and processed soy products. There was a significant positive relationship between knowledge and attitude. Allowance and attitude were positively related to the frequency of consumption. The number of types of functional food was only related to attitude. Factors that significantly influence the frequency of consumption were allowance and attitude. The number of types of functional food consumed only influence by attitude.

\section{Recommendation}

Recommendation that can be given for government is provide more socialisation about functional food and its benefits considering the low of student's knowledge about functional food. For food producers to properly record the information and claims of nutrition and with simple language to enable consumers to identify a product is functional food because there are still many food products including functional food, but do not have a good information label. 
For consumers, to start consume healthy food and beneficial to health and use the information media wisely so that knowledge about functional food better because of the still low awareness and knowledge of consumers about functional food. For further research, it is expected to study using random sampling proportional according to faculty.

\section{References}

Ares, G., Gambaro, A. (2007). Influence of gender, age and motives underlying food choice on perceived healthiness and willingness to try functional foods. Appetite, 49, 148-158.

Badan Pengawas Obat dan Makanan. (2011). Peraturan BPOM tentang pengawasan klaim dalam label dan iklan pangan olahan. Retrieved from jdih.pom.go.id

Beardsworth, A., Bryman, A., Keil, T., Goode, J., Haslam, C., Lancashire, E. (2002). Women, men and food: The significance of gender for nutritional attitudes and choices. British Food Journal, 104(7), 470-491. doi:10.1108/00070700210418767.

Bech-Larsen, T., Grunert, K.G. (2003). The perceived healthiness of functional foods: a conjoint study of Danish, Finnish and American consumers' perception of functional foods. Appetite, 40(1), 9-14. doi: 10.1016/S01956663(02)00171-X.

Bogue, J., Coleman, T., Sorenson, D. (2005).Determinants of consumer's dietary behaviour for health-enhancing foods. British Food Journal, 107(1), 4-16. doi:10.1108/00070700510573168.

Brečić, R., Gorton, M., Barjolle, D. (2014).Understanding variations in the consumption of functional foods-evidence from Croatia. British Food Journal, 16(4), 662 - 675.doi:10.1108/BFJ-05-2012-0133.

Carrillo, E., Fiszman, S., Prado-Gasco, V., Varela, P. (2013). Why buying functional foods? Understanding spending behaviour through structural equation modeling. Food Research International, 60(1), 361368.doi:10.1016/j.foodres.2012.10.045.

Chen, M. (2011).The joint moderating effect of health consciousness and healthy lifestyle on consumers' willingness to use functional foods in Taiwan.Appetite, 57(1), 253-262. doi: 10.1016/j.appet.2011.05.305.

De Jong, N., Hoendervangers, C.T., Bleeker, J.K., Ocké, M.C. (2004). The opinion of Dutch dietitians about functional foods.Journal of Human Nutrition and Dietetics, 17(1), 55-62. doi:10.1046/j.1365277X.2003.00498.x.

Departemen Kesehatan Republik Indonesia. (2009). Profil kesehatan Indonesia 2008. Retrieved from www.depkes.go.id

Dogan, I.S., Yildiz, O., Eyduran, E., Kose, S. (2011).A study on determination of functional food consumption habits and awareness of consumers in Turkey.Bulgarian Journal of Agricultural Sciences, 17(2), 246 - 257. doi:10.12691/jfnr-3-4-9. 
Florea, L., Filip, L., Banc, R. (2016). Consumers' knowledge, interest and attitude toward functional food in a Romanian population sample. Palestrica of the third millennium-Civilization and Sport, 17(1), 14-18.

Gilbert, L. (2000). Marketing functional foods: how to reach your target audience.AgBioForum,3(1), 20-38.

Khomsan, A., Anwar, F., Mudjajanto E.S. (2009). Pengetahuan, sikap, dan praktek gizi ibu peserta posyandu. Jurnal Gizi dan Pangan, 4(1), 33-41.

Krutulyte, R., Costa, A.I., Grunert, K.G. (2009). A cross-cultural study of cereal food quality perception.Journal of Food Quality Perception, 15(3), 304323. doi:10.1080/10454440902966884.

Marina, T., Marija, C., Ida, R. (2014).Functional Foods and the Young.Journal of Food Products Marketings, 20, 441-451. doi:10.1080/10454446.2013.838535.

Menrad, K. (2003). Market and marketing of functional food in Europe.Journal of Food Engineering, 56(2), 181-188.doi:10.1016/S0260-8774(02)00247-9.

Morawska, A., Cocorna, I., Boelawska, I., Przyslawski, J. (2016). The Nutritional Awareness of Functional Food Among University Students in Poland. Rocz Panstw Zakl Hig, 67(2), 163-167.

Muctahdi, D. (2012). Pangan Fungsional dan Senyawa Bioaktif. Bandung: Penerbit Alfabeta.

Ong, F.S., Kassim, N.M., Peng, O.S., Singh, T. (2014). Purchase behaviour of consumer of functional foods in Malaysia: an analysis od selecteddemographic variables, attitude and health status. Asia Pacific Management Review, 19(1), 81-95. doi:10.6126/APMR.2014.19.1.05.

Rezai, G., Teng, P.K., Mohamed, Z., Shamsudin, M.N. (2012). Functional food knowledge and perceptions among young consumers in Malaysia. InternationalJournal of Social, Behavioral, Educational, Economic, Business, and Industrial Engineering, 6(3), 307-312. Retrieved from https://waset.org/Publication/functional-food-knowledge-and-perceptionsamong-young-consumers-in-malaysia/11558.

Sääksjärvi, M., Holmlund, M., Tanskanen, N. (2009).Consumer knowledge of functional foods.The International Review of Retail, Distribution and Consumer Research,19, 135-156. Retrieved from http://www.informaworld.com/10.1080/09593960903109469.

Seechurn, D., Neeliah, H., Neeliah, S.A. (2009). Functional foods in mauritius: an exploratory survey. Journal of Developmental and Agricultural Economics,1(9), 204-211. Retrieved from: https://www.researchgate.net/ publication/213049661_Functional_Foods_in_Mauritius_An_Exploratory _Survey.

Siró, I., Kápolna, E., Kápolna, B., Lugasi, A. (2008). Functional food. Product development, marketing and consumer acceptance: A review. Appetite, 51(3), 456-467.doi:10.1016/j.appet.2008.05.060.

Sumarwan, U. (2011). Perilaku Konsumen. Ed ke-2. Bogor (ID): Penerbit Ghalia Indonesia.

Urala, N., Lähteenmäki, L. (2003). Reasons behind consumers' functional food choices.Nutrition \& Food Science, 33, 148-158. doi:10.1108/00346650310488499. 
Urala, N., Lähteenmäki, L. (2007). Consumers'changing attitudes towards functional foods. Food Quality and Preference, 18(1), 1-12. doi:10.1016/j.foodqual.2005.06.007.

Urala, N., Schutz, H., Spinksa, J. (2011). Consumer perceptions of "functional food" in the United States. Journal of Food Products Marketing, 17(4), 407-419.doi:10.1080/10454446.2011.583181.

Verbeke, W. (2005). Consumer acceptance of functional foods: sociodemographic, cognitive and attitudinal determinants. Food Quality and Preference, 16, 45-57.doi:10.1016/j.foodqual.2004.01.001.

Verbeke, W. (2005). Functional foods: Consumer willingness to compromise on taste for health? Food Quality and Preference, 17, 126-131. doi:10.1016/j.foodqual.2005.03.003

Wansink, B., Westgren, R.E.,Cheney, M.M. (2005). Hierarchy of nutritional knowledge that relates to the consumption of a functional food.Nutrition, 21(2), 264-268.doi:10.1016/j.nut.2004.06.022.

Winarti, S. (2010). Makanan Fungsional. Jakarta (ID): Penerbit Graha Ilmu. 